\title{
ОСИРОМАШЕН УРАНИУМ: РАДИОЛОШКА ИЛИ ТОКСИКОЛОШКА ОПАСНОСТ?!
}

\section{Кратка содржина}

Тековно на нашиов простор се актуелни бројни извештаи за здравствени проблеми и телесни оштетувања, наводно, предизвикани од употребата на осиромашен ураниум при интервенцијата на Алијансата во Сојузна Република Југославија. Извештаите од борбените дејства во Заливската војна во кои била употребена ваквата мунииија предупредуваат дека состојбата на бојните полиња и долготрајните ризици за здравјето кај месното население и воените ветерани можат да станат еден од главните проблеми за континуираната употреба на $O У$ за воени иели. Авторот се обидува да покаже дека општата загриженост е само делумно оправдана. Биолошките ефекти на ОУ се слични, но послаби од оние на природниот ураниум. Сѐ додека останува надвор од телото, ОУ не претставува значајно загрозување за живиот свет. Иако испитувањата укажуваат дека радијациските ефекти регистрирани во постконфликтните подрачја се само мал дел од ефектите на природната радијачија и дека хемиската токсичност на ураниумот е неговата поголема опасност, сепак, поради општата недоверба со која многу луѓ гледаат на овој (радијачиски) проблем, радиолошките и токсиколошките карактеристики на осиромашениот ураниум треба да се застапат во обуката и едукацијата на чивилите и вооружените сили, како начин за намалување на постоечката параноја. Исто така, за да се намали и опасноста од ризик, ке треба соодветно да бидат дистрибуирани знаењето, експертизата и заититната опрема во области на можна употреба на осиромашен ураниум.

Клучни зборови: ОСИРОМАШЕН УРАНИУМ, ИЗОТОПИ, ЕФЕКТИ, РАДИОАКТИВНОСТ, ТОКСИЧНОСТ, ЛИМИТИ.

\section{Вовед}

Во Периодичниот систем на елементите во скалата според зголемување на масата во јадрата, ураниумот е најтешкиот од сите елементи во природата. Ураниумот има релативна специфична тежина од 18,7. (Таа е бездимензионална величина која претставува однос помеѓу тежината на дадено тело и тежината на ист волумен вода). Ураниумот бил формиран во супер нова приближно пред 6,6 милијарди години. Откриен е во 1789 година во минерал наречен Pitchblende a името го добил по планетата Уран, која е откриена осум години порано. Иако е едвај радиоактивен, помалку отколку многу други изотопи во карпите и песокот, сепак, тој генерира енергија (кинетичка топлина) од 0,1 wat/тон што е доволно да ја загрее Земјината кора. Ураниумската руда содржи три уранимуски изотопи 
(ураниум-238, ураниум-235 и ураниум-234) во релативно прецизен утврден однос. Ураниум-238 е најзастапен изотоп во ураниумската руда, со полуживот од 4,46 милјарди години. Ураниум-238 се распаѓа со алфа-емисија во ториум-234, кој самиот се распаѓа со бета-емисија до протактиниум-234, кој се распаѓa со бета-емисија до ураниум-234 итн. Абунданцијата и карактеристиките на изотопите на ураниумот се поместени во Табела 1.

Табела 1: Приказ на ураниумските изотопи

\begin{tabular}{|c|c|c|c|c|}
\hline Изотопи & $\begin{array}{c}\text { Процент во } \\
\text { природниот } \\
\text { ураниум } \\
\text { (абунданција) }\end{array}$ & $\begin{array}{c}\text { Број на } \\
\text { протони }\end{array}$ & $\begin{array}{c}\text { Број на } \\
\text { неутрони }\end{array}$ & $\begin{array}{c}\text { Полуживот } \\
\text { (во години) }\end{array}$ \\
\hline Ураниум-238 & 99.284 & 92 & 146 & 4.46 милјарди \\
\hline Ураниум-235 & 0.711 & 92 & 143 & 704 милиони \\
\hline Ураниум-234 & 0.0055 & 92 & 142 & 245,000 \\
\hline
\end{tabular}

Различните продукти на распадот (понекогаш именувани како „потомци“ или „ќерки“) формираат серии започнувајќи со ураниум-238. По неколку алфа и бета-распади, серијата завршува со стабилен изотоп олово-206. Ураниум-238 емитира алфа-честички кои потешко пенетрираат во материјата во споредба со останатите форми на зрачење и слаби гама-зраци. Изотопот ураниум-235 е значаен поради својството во одредени услови да може да се дели, при што ослободува голема количина енергија. Поради тоа е наречен фисибилен и се употребува изразот нуклеарна (јадрена) фисија. Исто како и другите радиоактивни изотопи, тој трпи алфа $(\alpha)$ распад.

Сѐ додека останува надвор од телото, ураниумот поседува мал ризик за здравјето (главно од гама-зраците). Ако е вдишан или внесен во дигестивниот систем, неговата радиоактивност носи зглемен ризик од рак на белите дробови и коските. Ураниумот во високи концетрации, исто така, е хемиски токсичен и може да предизвика оштетувања на внатрешните органи, особено на бубрезите. Студиите со животни укажуваат дека ураниумот може да влиијае врз репродукцијата, врз фетусот во развој, и да го зголеми ризикот од леукемија и рак на мекото ткиво. 
Табела 2

ВЕРИГА НА УРАНИУМСКИОТ РАСПАД - гЛавНа Гранка читај одлево кон десно. - Стрелките $(\Longrightarrow)$ означуваат распад

\begin{tabular}{|c|c|c|}
\hline $\begin{array}{l}\text { Ураниум-238 ==> } \\
\text { (полуживот: } 4.46 \text { милијарда } \\
\text { години) } \\
\text { алфа-распад }\end{array}$ & $\begin{array}{l}\text { Ториум-234 => } \\
\text { (полуживот: } 24.1 \text { дена) } \\
\text { бета-распад }\end{array}$ & $\begin{array}{l}\text { Протактиниум-234m ==> } \\
\text { (полуживот : } 1.17 \text { минути) } \\
\text { бета-распад }\end{array}$ \\
\hline $\begin{array}{l}\text { Ураниум-234 } \Longrightarrow \\
\text { (полуживот: } 245,000 \text { годи- } \\
\text { ни) } \\
\text { алфа-распад }\end{array}$ & $\begin{array}{l}\text { Ториум-230 }=> \\
\text { (полуживот: } 75,400 \text { години ) } \\
\text { алфа-распад }\end{array}$ & $\begin{array}{l}\text { Радиум-226 => } \\
\text { (полуживот: 1,600 години) } \\
\text { алфа-распад }\end{array}$ \\
\hline $\begin{array}{l}\text { Радон-222 }=> \\
\text { (полуживот: } 3.82 \text { дена ) } \\
\text { алфа-распад }\end{array}$ & $\begin{array}{l}\text { Полониум-218 ==> } \\
\text { (полуживот: } 3.11 \text { минути ) } \\
\text { алфа-распад }\end{array}$ & $\begin{array}{l}\text { Олово-214 ==> } \\
\text { (полуживот: } 26.8 \text { минути ) } \\
\text { бета-распад }\end{array}$ \\
\hline $\begin{array}{l}\text { Бизмут-214 }=> \\
\text { (полуживот: } 19.9 \text { минути ) } \\
\text { бета-распад }\end{array}$ & $\begin{array}{l}\text { Полониум-214 } \Longrightarrow \\
\text { (полуживот: } 163 \text { микросе- } \\
\text { кунди) } \\
\text { алфа-распад }\end{array}$ & $\begin{array}{l}\text { Олово- } 210=> \\
\text { (полуживот: } 22.3 \text { години) } \\
\text { бета-распад }\end{array}$ \\
\hline $\begin{array}{l}\text { Бизмут- } 210==> \\
\text { (полуживот: } 5.01 \text { дена) } \\
\text { бета-распад }\end{array}$ & $\begin{array}{l}\text { Полониум-210 ==> } \\
\text { (полуживот: } 138 \text { дена) } \\
\text { алфа-распад }\end{array}$ & $\begin{array}{l}\text { Олово-206 } \\
\text { (стабилен) }\end{array}$ \\
\hline
\end{tabular}

\section{1. Добивање ураниум и осиромашен ураниум}

Традиционално, ураниумот се добива од отворени јами и подземни ископи (рудници). Во минатата декада, алтернативни техники како што е квасење во место (ISL), при што се инјектирани раствори во подземните наслаги за да се раздвои ураниумот, станаа почесто користени. „Во т.н. кисела постапка, растворувачот е обично воден раствор на сулфурна киселина, раствор во кој ураниумот се наоѓa како уранил сулфат. Кога рудата, пак, содржи доволно варовник, најчесто се користи базната постапка, во која растворувачот е сода, така што во растворот ураниумот е во облик на уранил карбонат. Откако растворот физички ќе се прочисти, од него се добива концентрат на ураниум во облик на ураниум оксид. Издвојувањето на концентратот се врши или со таложење откако ќе се додадат соодветни реагенси, или со јонска измена, или со екстракција со помош на други селективни растворувачи“ (Рopović 1978, 117).

Процесот на рафинирање претпоставува извлекување на ураниум оксид $\left(\mathrm{U}_{3} \mathrm{O}_{8}\right)$ од рудата до форма жолт колач - жолт или кафен прав кој содржи околу $90 \%$ ураниум оксид. Традиционалните техники на копање во фазата на рафинирање генерираат значаен квантитет на измелени безвредни остатоци, бидејќи корисниот дел, генерално, е помал од еден процент од рудата. Bo ISL-техниката останува неискористен дел во земјата кој не се смета за отпад. 
Пред ураниумот да биде употребен во реактор за добивање енергија, тој мора да помине низ цела низа процеси сѐ до фазата на употребливо гориво. Имено, ураниум оксидот $\left(\mathrm{U}_{3} \mathrm{O}_{8}\right)$ мора да се претвори во гас ураниум хексафлорид $\left(\mathrm{UF}_{6}\right)$ - форма која овозможува збогатување. Ураниумот, кој главно се употребува во реакторите, е во форма на ураниум диоксид $\left(\mathrm{UO}_{2}\right)$ или ураниумски метал. Нуклеарните оружја, исто така, ја користат металната форма. Производството на $\mathrm{UO}_{2}$ (како метал) побарува хемиски процес на т.н. жолт колач. Повеќето цивилни и воени реактори побаруваат ураниум кој има повисок процент на ураниум-235 отколку оној присутен во природниот ураниум. Процесот кој се користи за зголемување на количеството на урнаиум- 235 во однос на ураниум-238 е познат како ураниумско збогатување. Така, на пример, цивилните нуклеарни централи во САД употребуваат 3-5\% ураниум-235 а сите нуклеарни оружја употребуваат високо збогатен ураниум (HEU) со повеќе од 90 проценти ураниум-235. (Некои истражувачки реактори и сите нуклеарни реактори во морнарицата на САД, исто така, користат високо збогатен ураниум).

Повеќето од отпадот од процесот на ураниумско збогатување го сочинува осиромашениот ураниум (ОУ), наречен така поради тоа што најголемиот дел од ураниумот- 235 е извлечен од него.

\section{2. Исполување на штетното дејство на ОУ}

\section{1. Хемиска токсичност и токсиколошки лимити за внесениот ура-} ниум

Хемиската токсичност на ОУ претставува најголема опаснсот за здравјето за краток период (од неколку недели или месеци) по изложеноста. Бубрезите се сметаат за критичен орган на ураниумската хемиска токсичност.

Бубрезите филтрираат околу 160-200 литри крв секој ден. Основната морфолошка единица на бубрегот е нефронот. Секој бубрег се состои од околу 2 милиона нефрони. Еден од главните делови на нефронот претставува сплет од артериски капилари именуван како гломерулот. Главната функциа на гломерулот е да служи како сито за плазмата, при што малите јони и молекули како што се водата, содиумски јони, гликоза и амино киселини се филтрираат, додека поголемите молекули како што се протеините не се филтрираат. Со контролирање на нивото на електролити во крвта (како јоните на содиум и бикарбонат) бубрезите ја одржуваат киселоста на крвта помеѓу рН 7,35 -7,45. Кога вредноста паѓа под ова ниво, состојбата е наречена кисела, а кога рН е над, е наречена алкална. Главниот ефект од умерената киселина е депресија на централниот нервен систем, дезориентација и замор. Главниот ефект од умерената алкалност е хиперексцитација на нервниот систем, спонтана стимулација на мускулите и екстремна нервоза (Saladin 1999). Сите овие симптоми се меѓу првите 10 проблеми кои се објавени од ветераните на Заливската војна од 1991 година (Nicolson and Nicolson 1998, 74-83).

Ураниумот во бубрезите дејствува првенствено на примарното каналче (тубул). Разложените состојки од уранил карбонат во оваа кисела средина се распаѓаат до уранил $\left(\mathrm{UO}_{2}\right) 2+$ и бикарбонат $\left(\mathrm{HCO}_{3}\right)^{-}$јони. Како што живата, кадми- 
умот и др. јони на тешки метали, така и јоните на уранил ја потиснуваат гломеруларната функција, тубуларната секреција на органски анјони (кисели метаболички отпади како лактат, цитрат и сл.) и реапсорпцијата на филтрираната гликоза и аминокиселини во примарното каналче.

Кога неорганските $\mathrm{Cd}, \mathrm{Hg}$ или други тешки метали ќе се инјектираат во реналната артерија, овие метални јони веднаш стануваат заробени од недифузибилни макромолекули како плазма протеини и стануваат нефилтрабилни во гломерулот. Уранилски јони кои се разложени можат да реагираат со дифузибилни желирачки состојки до форма на релативно стабилни и инертни соединенија. Овие неподвижни соединенија потоа се филтрираат и се исфрлаат во урнината. Вакви желатирачки состојки во експерименти биле обезбедени кај лабораториските животни веднаш по изложувањето на ураниум. Оваа желе терапија резултира со зголемено исфрлање на ураниум (Clarke et al. 1998).

Од посебен интерес за женската популација се проучувањата со лабораториски животни кај кои ураниумот е најден во плацентата, фетусот и млекото од женките и во ткивото и урината кај младенчињата кои биле хранети со млекото од женките кои биле изложувани на ураниум. Ефектите биле рангирани од недоволна тежина кај новородените до скелетни абнормалности за дозите кај кои мајките покажувале знаци на хемиска токсичност. Осиромашен ураниум (ОУ), меѓу, другото, бил најден и во примероците на сперма кај некои ветерани од Заливската војна кои биле изложени на ОУ.

Максимално дозволена професионална концентрација за растворливиот ураниум кој содржи помалку од 5\% од U-235 (вклучувајќи го природниот, осиромашениот, како и ураниум збогатен за реакторски потреби) која е $0,2 \mathrm{mg} / \mathrm{m}^{3}$ за 40 часа (според Комисијата за нуклеарна регулација - NRC) е порестриктивна отколку радиолошкиот лимит во Табела 3 токму поради ураниумската хемиска токсичност. Засновано на околу $34 \mathrm{~m}^{3}$ респириран воздух за наведеното време, со $25 \%$ од вдишаниот ураниумски прав заробен во белите дробови и $50 \%$ проголтан, оваа воздушна концентрација би кореспондирала со внесување растворлив ураниум од $5,1 \mathrm{mg} / \mathrm{kg}(1,7 \mathrm{mg} /$ неделно во градите и $3,4 \mathrm{mg} /$ неделно во гастроинтестиналниот тракт). Според некои истражувања (Agency for Toxic Substances and Disease Registry 2013), само $12 \%$ од вкупно ингестираниот ураниум (растворлив и нерастворлив) е апсорбиран од цревата во крвта за време од 6 дена пред остатокот да биде излачен преку фекалии. Како многу малку нерастворлив ураниум може да навлезе во крвотокот, разумно би било да се претпостави дека делот на растворлив ураниум ја удвојува вредноста на околу $25 \%$. Последично, ураниумското полнење во крвта би било само $2,5 \mathrm{mg} /$ неделно $(1,7 \mathrm{mg} /$ неделно од градите и $0,8 \mathrm{mg} /$ неделно од гастроинтестиналниот (ГИ) тракт. По 10-12 работни недели (работна недела = 40 часа) на изложување над нормалната граница, $95 \%$ од заситената ураниумска концентрација во бубрезите ќе биде достигната:

$$
\mathrm{C}=\frac{\mathrm{T}}{\ln 2} \frac{\mathrm{kU}}{\mathrm{m}}=3 \mathrm{mg} / \mathrm{kg}
$$


Во последнава формула, $\mathrm{U}=0.36 \mathrm{mg} /$ ден е просечното дневно внесување ураниум во крвта, $\mathrm{K}=11 \%$ е количината на ураниумскиот депозит во бубрезите, $\mathrm{T}=15$ дена е полуживотот за екскреција на депонираниот ураниум $\ln 2=0,693$ и „m=0,29 kg е комбинираната тежина од двата бубрега за телесна тежина од $70 \mathrm{~kg}$ и 1:240 однос меѓу комбинираната тежина од двата бубрега и телесната тежина (Gray 1977).

Дозволените граници за тунгстен, оловна и ураниумска инхалација утврдени од Администрацијата за здравство и безбедност при работа (OSHA) се презентирани во Табела 4. Забележливо е дека максималната воздушна концентрација за растворливиот ураниум е 4 пати помала отколку NRC дозволените граници и затоа би резултирало со заситена концентрација од $750 \mu \mathrm{g} / \mathrm{kg}$ во бубрезите.

Табела 3. NRC професионални воздушни концентрации

\begin{tabular}{|c|c|c|c|}
\hline Растворливост & $\begin{array}{c}\alpha \text {-активност } \\
{\left[\mathrm{pCi} / \mathrm{m}^{3}\right]}\end{array}$ & $\begin{array}{c}\text { У маса } \\
{\left[\mu \mathrm{g} / \mathrm{m}^{3}\right]}\end{array}$ & $\begin{array}{c}\text { OУ мaca } \\
{\left[\mu \mathrm{g} / \mathrm{m}^{3}\right]}\end{array}$ \\
\hline Нерастворлив & 20 & 30 & 52 \\
\hline Растворлив & 500 & 740 & 1300 \\
\hline
\end{tabular}

Растворливиот ураниум ја покажува приближно истата хемиска токсичност како и растворливото олово и е околу 20 пати повеќе токсичен во споредба со растворливиот тунгстен, алтернативниот материјал за оклопно-пробива муниција. Токсичниот лимит за воздушна концентрација на нерастворливот ураниумски прав на OSHA е високо надминат, бидејќи NRC изведената радиолошка воздушна концентрација за нерастворливиот природен и осиромашен ураниумски прав е 8,3 х и 4,6 х помала од овој лимит (види Табела 3).

Табела 4. OSHA професионални инхалациони лимити

\begin{tabular}{|c|c|c|}
\hline Елемент & $\begin{array}{c}\text { Растворлив } \\
{\left[\mathrm{mg} / \mathrm{m}^{3}\right]}\end{array}$ & $\begin{array}{c}\text { Нерастворлив } \\
{\left[\mathrm{mg} / \mathrm{m}^{3}\right]}\end{array}$ \\
\hline Тунгстен & 1 & 5 \\
\hline Олово & 0.05 & 0.10 \\
\hline Ураниум & 0.05 & 0.25 \\
\hline
\end{tabular}

Минимално ризик-ниво за ингестија со средно траење што е јавно предложено од Агенцијата за токсични супстанции и регистар на болести (ATSDR) е орално внесување ураниум на ниво од $1 \mu \mathrm{g} /$ ден за секој килограм од телесна тежина, засновано на најнови испитувања вршени со глувци при дози од $1,1 \mu \mathrm{g} /$ ден/ $\mathrm{kg}$. За телесна тежина од $70 \mathrm{~kg}$ ова кореспондира со ураниумска доза од $500 \mu \mathrm{g}$ неделно во гастроинтестиналниот тракт и заситена концентрација од $150 \mu \mathrm{g} / \mathrm{kg}$ во бубрезите. Малку пониска толерантна доза од $07 \mu \mathrm{g} /$ ден $/ \mathrm{kg}$ е предложена, заснована, исто така, на најнови ефекти при истражување на бубрезите на зајаци, што ко- 
ренспондира со ураниумска доза од $350 \mu \mathrm{g} /$ неделно во ГИ (гастроинтестиналниот) тракт и засилена концентрација од $100 \mu \mathrm{g} / \mathrm{kg}$ во бубрезите.

Табела 5. ЕРА стандарди за вода

\begin{tabular}{|c|c|c|}
\hline Вода & $\begin{array}{c}\boldsymbol{\alpha} \text {-активност } \\
{[\mathrm{pCi} / \mathrm{L}]}\end{array}$ & $\begin{array}{c}\text { Maca } \\
{[\mu \mathrm{g} / \mathrm{L}]}\end{array}$ \\
\hline Површинска вода & 30 & 44 \\
\hline Вода за пиење & 13.5 & 20 \\
\hline
\end{tabular}

Според Агенцијата за заштита на околината (ЕРА), тековните стандарди за површинската вода кај неактивни ураниумски процесни објекти и предложените стандарди за вода за пиење (види Табела 5) се засновани на овие толерантни дози и на просечното дневно консумирање вода.

Кога се работи за хронична изложеност на ураниум, неодамнешна студија за ефектите од хронична ингестија на ураниум со вода за пиење кај луѓето открива дека функцијата на бубрезите е нападната под влијание на ураниумските дози кои претходно се сметале за сигурни, а биле засновани на истражувања со животни. Субјектите при овие студии биле поделени во две групи: група на ниска изложеност (20 субјекти), кои пиеле вода од јавен водовод која содржела помалку од $1 \mu \mathrm{g} / 1$ ураниум; и група на висока изложеност (30 субјекти), чија вода за пиење била обезбедена од приватни бунари кои содржеле од 2-781 $\mu \mathrm{g} / \mathrm{l} \mathrm{ypa-}$

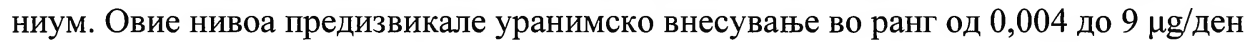
по $1 \mathrm{~kg}$ од телесната тежина. Изложената група во споредба со контролната група исфрлала многу повеќе гликоза во урината. Исфрлањето на алкални фосфати (кои се маркер за клеточна токсичност) и на $\beta-2$ микроглобулин (маркер за проксимална тубуларна функција) било во пропорција со ураниумското внесување.

Истражувањето заклучува дека долготрајна ингестија на ураниум при покачено ниво на ураниум во изворите на вода кај луѓето може да продуцира нарушување на функцијата на бубрезите. Набљудувањата покажуваат дека не е секогаш ефектот откажување на бубрезите или нивно заболување, но може да биде прв чекор кој води до прогресивно или неповратно оштетување. Лицата кои биле претходно изложени на ураниум се во поголем ризик во случај на подоцнежно заболување на бубрезите отколку неизложените лица, при што се знае дека $25 \%$ од реналната функција може да се загуби пред проблемите да бидат откриени и до $75 \%$ пред да бидат установени јасни клинички симптоми.

\section{2. Радиолошки ефекти на ураниумот}

Радијацијата е присутна насекаде. Луѓето во секојдневниот живот се постојано бомбардирани со гама-зраци, неутрони и наелектризирани честички - сите продуцирани од материјали во природата, па дури и во нивните сопствени тела. Оваа постојано присутна радијација опстојува од самото постоење на Земјата. Луѓето еволуирале и се развиле во ваквата околина на јонизирачко зрачење. 
Кога се зборува за здравствените ефекти поврзани со јонизирачкото зрачење, се употребува терминот „доза“. „Доза“ доаѓа од поранешна употреба на хзраците во медицината, исто како и дозата која во медицината се мери во грамови. Се однесува на количеството радиоактивна енергија апсорбирана од орган, ткиво, клетка, изразена во сиверти (1sv= 100 REM). „За еден животен век од 70 години, просечната доза е 21 rem" (Board on Radiation Effects Research Division on Earth and Life Studies 2003, 19). Во некои делови на светот луѓето примаат многу повисока доза од секојдневната т.н. заднинска радијација. Така, на пример, во некои делови од Индија и Бразил површината е покриена со песок моназит - радиоактивна руда. Степенот на радијациска изложеност таму е неколку пати колку просечната заднинска радијација на друго место. Луѓето кои живеат во овие области примаат дози од околу 0,7 реми секоја година само од $\gamma$ - радијација. Овие нивоа комбинирани со другите извори на заднинска радијација (како што се космичките зраци, радон и др.) прават таму просечните дози да се дури и до 3 пати повисоки од општоприфатената доза. Сепак, овие луѓе не покажуваат повисок степен на заболени од рак или други болести поврзани со радијацијата.

Ефектите од јонизирачкото зрачење може да се категоризират како брзи или одложени, засновани на времето во кое тие ефекти се набљудувани. Брзите ефекти, како што е брза смрт, се случуваат кога високи дози се примени во кус период од часови до недели. Одложените ефекти, како што е канцер, се случуваат кога комбинацијата од дозата и степенот на дозата се мали за да предизвикаат брзи ефекти. И испитувањата со животните и човечките изложувања на високи нивоа од зрачење покажуваат дека јонизирачкото зрачење предизвикува рак.

За ниските дози не постојат прецизни податоци за да можат дозите да се поврзат со одредени здравствени последици или, пак, некакво минимално ниво за канцер. Поради ова, експертите кои ги проучуваат ефектите од зрачењето имаат одлучено дека резултатите од високите дози ќе бидат од корист при контрола на ниските дози што ги претрпеле работниците кои работат со извори на зрачење и јавноста пошироко. Поради тоа што степенот при кој ефектот се случува е екстраполиран од повисоките дози, се претпоставува дека ефектот расте линеарно со дозата. Овие две претпоставки се познати како „одговор на линеарна доза“ и „без збир“ хипотези. Тоа покажува дека ист број на рак заболувања настапуваат при изложување 100 лица на 100 реми, или 10 илјади лица на 1 рем, или 10 милиони лица на 0,001 рем.

Ефектите од зрачењето врз материјата се карактеризираат со радијацијска доза, или апсорбирана енергија по единица маса. Дозата се изразува во единица Греј $(1 \mathrm{~Gy}=1 \mathrm{~J} / \mathrm{kg})$. Со цел да се изнивелираат биолошките ефекти на различни типови радијација ( $\alpha, \beta, \gamma$ или неутрони), апсорбираната доза се мултиплицира со фактор на релативна биолошка ефикасност (RBE). Крајната величина е наречена еквивалентна доза и се мери во Сиверти (1Sv=RBE x 1Gy). „RBE факторот е $1 \mathrm{~Sv} /$ Gy за $\beta$ и $\gamma$ радиација, $20 \mathrm{~Sv} / \mathrm{Gy}$ за $\alpha$ радиација под $2 \mathrm{MeV}$, и етапно паѓа до 2,5 $\mathrm{Sv} / \mathrm{Gy}$ за $\alpha$ честици со енергија од $100 \mathrm{MeV}$. Но, енергијата на $\alpha$-честичката од радиоактивниот распад е секогаш помеѓу 2-9 MeV, па Комисијата за нуклеарно ре- 
гулирање (NRC) едноставно го користи RBE-факторот од $20 \mathrm{~Sv} / \mathrm{Gy}$ за сите $\alpha$-емитери“" (Leo 1987, 67).

Табела 6. Еквивалентна доза за ураниумски изотопи и продукти на распадот (*за $\beta$-радијација, максимум енергија од $\beta$-спектарот)

\begin{tabular}{|c|c|c|c|c|c|}
\hline Изотоп & Радијација & $\begin{array}{c}\text { Енергија } \\
{[\mathrm{keV}]}\end{array}$ & $\begin{array}{c}\text { Приход } \\
\text { [\%] }\end{array}$ & $\begin{array}{c}\mathrm{RBE} \\
{[\mathrm{rem} / \mathrm{rad}]}\end{array}$ & $\begin{array}{c}\text { Еквивалентна } \\
\text { доза } / \text { aктивност } \\
{[(\mathrm{mrem} / \mathrm{year}) /(\mathrm{pCi} / \mathrm{kg})]}\end{array}$ \\
\hline \multirow{3}{*}{${ }^{238} \mathrm{U}$} & $\alpha$ & 4,267 & 77 & 16 & \multirow{3}{*}{1.28} \\
\hline & $\alpha$ & 4,219 & 23 & 16 & \\
\hline & $\gamma$ & 48 & 23 & 1 & \\
\hline \multirow{3}{*}{${ }^{234} \mathrm{Th}$} & $\beta^{-}$ & 193 & 67 & 1 & \multirow{3}{*}{0.0028} \\
\hline & $\beta^{-}$ & 100 & 33 & 1 & \\
\hline & $\gamma$ & 93 & 33 & 1 & \\
\hline \multirow{5}{*}{${ }^{234 \mathrm{~m}} \mathrm{~Pa}$} & $\beta^{-}$ & 2,290 & 98 & 1 & \multirow{5}{*}{0.0146} \\
\hline & $\beta^{-}$ & 1,480 & 1 & 1 & \\
\hline & $\beta^{-}$ & 1,250 & 1 & 1 & \\
\hline & $\gamma$ & 810 & 2 & 1 & \\
\hline & $\gamma$ & 230 & 1 & 1 & \\
\hline \multirow{3}{*}{${ }^{234} \mathrm{U}$} & $\alpha$ & 4,856 & 72.5 & 15 & \multirow{3}{*}{1.30} \\
\hline & $\alpha$ & 4,803 & 27.5 & 15 & \\
\hline & $\gamma$ & 53 & 27.5 & 1 & \\
\hline${ }^{235} \mathrm{U}$ & $\alpha$ & 4,678 & 100 & 15 & 1.32 \\
\hline${ }^{231} \mathrm{Th}$ & $\beta^{-}$ & 387 & 100 & 1 & 0.0024 \\
\hline
\end{tabular}

Еквивалентните дози за индивидуални ураниумски изотопи и нивните продукти на распад униформно дистрибуирани во индивидуални органи или во целото тело се дадени во Табела 6. Пресметувањето на годишната еквивалентна доза DE од специфичната активност $1 \mathrm{pCi} / \mathrm{kg}$ од чист $\alpha$-емитер како U-235 е едноставно:

$$
\mathrm{DE}=\mathrm{RBE} \times \mathrm{E} \alpha \mathrm{RY}=1,32 \times 10^{-5} \mathrm{~Sv} \text { година, }
$$

каде што $\mathrm{RBE}=15 \mathrm{~Sv} / \mathrm{Gy}$ е релативна биолошка ефикаснсот, $\mathrm{E} \alpha=4,678 \mathrm{MeV}=7$, $527 \times 10^{-13} \mathrm{~J}$ е енергија на $\alpha$-честичките, $\mathrm{P}=1 \mathrm{pCi} / \mathrm{kg}=3,7 \mathrm{~h} 10^{-2} \mathrm{~Bq} / \mathrm{kg}$ е специфичната $\alpha$-активност под претпоставка, и $\mathrm{Y}=3,156 \times 10$ на sec/година е бројот на секундите во една година. Во пресметувањето на еквивалентната доза од $\beta$-радијација, се зема дека околу $2 / 3$ од максималната енергија е однесена од неутрината, а неапсорбирана во материјата. Еквивалентната доза од $\alpha$-емитерите далеку ја надминува онаа од $\beta$-емитерите кога изворот на зрачење е внатре во телото. Еквивалентните дози од природниот и осиромашениот ураниум униформно дистрибуирани во целото тело или во индивидуални органи покажуваат дека степенот на 
изложеност со осиромашен ураниум (ОУ) е за 43\% помал во споредба со природниот ураниум при иста масова концентрација.

\section{3. Лимити на радијациска изложеност}

„Меѓународната комисија за радиолошка заштита (ICRP) предлага лимит на годишна еквивалентна доза за целото тело не поголема од $0.05 \mathrm{~Sv} /$ година и не повеќе од 0.1 Sv во 5 години“ (ICRP 1980). Никакви краткотрајни ефекти врз здравјето (никакви промени во крвта) не се откриени во оваа еквивалентна доза. Лими-

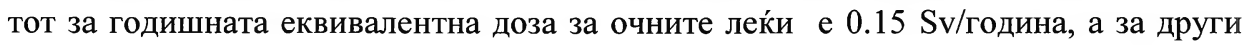
индивидуални органи и екстремитетите (раце или стапала) $0.5 \mathrm{~Sv} /$ година. За споредба, настанувањето на акутна радијациска болест (повраќање, дијареја, паѓање на косата, анемија, хемофилија, катаракта, привремен стерилитет кај мажите итн.) се случува при краткотрајно изложување на еквивалентни дози помеѓу 0.5-1 Sv. Без медицинска грижа, 50\% смртност е забележана на 2.5-3 Sv, примарно поради недостаток на имунитет при откажување на коскената срж. Со модерна медицинска грижа, 100\% преживување е можно при краткотрајни еквивалентни дози и до $10 \mathrm{~Sv}$.

Поради тоа што еквивалентната доза предложена од ICRP не покажува ни најмалку онаква опасност од долготрајните ефекти врз здравјето, како што е ракот, како безопасен лимит на годишен еквивалент-доза за јавноста е избран $1 \mathrm{mSv}$ /година, кој е споредлив со севкупниот просечен од $3.63 \mathrm{mSv} /$ година (2 mSv/година за радон, $1 \mathrm{mSv} /$ година од космичката радијација, Земјиното и внатрешното зрачење, и $0.63 \mathrm{mSv} /$ година од артифицијалните извори како медицински испити и потрошувачки продукти).

\section{1. Радиолошки лимити за внесениот (внатре во телото) ураниум}

Според NRC, годишниот лимит на внесениот ураниум (види Табела 7) е заснован на годишната еквивалентна доза од $0.05 \mathrm{~Sv} /$ година и на степенот на ураниумска екскреција во урината. Лимитот за инхалираниот нерастворлив ураниум е значително понизок отколку оној за инхалиран растворлив ураниум, бидејќи инхалираниот растворлив ураниум навлегува во крвотокот и се исфрла преку урината, додека вдишаните честички од нерастворлив ураниум остануваат наталожени во белите дробови со години. Бидејќи нерастворливиот ураниум не може да навлезе во крвотокот кога е ингестиран, затоа е даден само еден лимит за ингестираниот ураниум.

Табела 7. NRC професионален годишен лимит за ураниумско внесување

\begin{tabular}{|c|c|c|c|c|}
\hline Внесување & Растворливост & $\begin{array}{c}\alpha \text {-активност } \\
{[\mu \mathrm{Ci} / \text { year] }}\end{array}$ & $\begin{array}{c}\text { У Maca } \\
{[\mathrm{g} / \text { year] }}\end{array}$ & $\begin{array}{c}\text { OУ Maca } \\
\text { [g/year] }\end{array}$ \\
\hline Инхалација & Нерастворлив & 0.05 & 0.074 & 0.13 \\
\hline Инхалација & Растворлив & 1 & 1.5 & 2.6 \\
\hline Ингестија & $?$ & 10 & 1.5 & 26 \\
\hline
\end{tabular}


Границите за $\alpha$-активност на концентрациите од природен и осиромашен ураниум се идентични. Радиолошките лимити за масена концентрација можат да се пресметаат едноставно со делење на лимитите на $\alpha$-активност од природниот и осиромашениот ураниум од Табела 8 . Врз основа на тоа што $43 \%$ пониска специфична $\alpha$-активност од осиромашениот ураниум, радиолошките лимити за масовата концентрација од осиромашениот ураниум се $1 /(1-0,43)=1,75$ пати повисоки во споредба со тие од природниот ураниум.

\section{2. Лимити за надворешна изложеност на осиромашен ураниум}

Како спореден продукт при производството на збогатен ураниум, осиромашениот ураниум (OУ) е достапен материјал со ниска цена. Неговата висока специфична густина $(19,05 \mathrm{~g} / \mathrm{cm} 3$ што е 1,7 пати повеќе отколку на оловото - 11,35 $\mathrm{g} / \mathrm{cm} 3)$ и неговиот висок атомски број $\mathrm{Z}=92$ обезбедува успешна можност за заштита од $\gamma$-радијација. Ваквите негови карактеристики придонесуваат тој да биде една од можностите за обезбедување противтежа (балансирање) кај леталата. Тој, исто така, е прилично успешен материјал за изработка на индустриски антирадијациски штитови, за воени оклопи и противоклопна пробивна муниција.

Табела 8. Специфична активност на ураниумот

\begin{tabular}{c|c|c|c|c} 
Ураниум & $\begin{array}{c}\text { Активност } \\
\text { (вкупна) } \\
{[\mathrm{MBq} / \mathrm{kg}]}\end{array}$ & $\begin{array}{c}\alpha \text {-активност } \\
{[\mathrm{MBq} / \mathrm{kg}]}\end{array}$ & $\begin{array}{c}\text { Активност } \\
\text { (вкупна) } \\
{[\mathrm{mCi} / \mathrm{kg}]}\end{array}$ & $\begin{array}{c}\alpha \text {-активност } \\
{[\mathrm{mCi} / \mathrm{kg}]}\end{array}$ \\
\hline${ }^{238} \mathrm{U}$ & 12.4 & 12.4 & 0.335 & 0.335 \\
\hline${ }^{235} \mathrm{U}$ & 78.4 & 78.4 & 2.12 & 2.12 \\
\hline $\begin{array}{c}\text { Природен ура- } \\
\text { ниум со своите } \\
\text { потомци }\end{array}$ & 50.4 & 25.2 & 1.36 & 0.681 \\
\hline $\begin{array}{c}\text { Осиромашен } \\
\text { ураниум со } \\
\text { своите потом- } \\
\text { ци }\end{array}$ & 39.3 & 14.4 & 1.06 & 0.389 \\
\hline Модерно олово & $660 \times 10^{-6}$ & $220 \times 10^{-6}$ & $18 \times 10^{-6}$ & $6 \times 10^{-6}$
\end{tabular}

Алуминиумска кошулица кај проектилот од ОУ обезбедува заштита од $\alpha$ честици. $\alpha$-честиците не можат да ја пробијат надворешната обвивка на кожата, па дури и ако потекнуваат од соголен ОУ-ски пенетратор. „Еквивалентната доза за кожата од $\beta$ и $\gamma$-емисија на ураниумските потомци во соголен ОУ-ски проектил во директен контакт со кожата е приближно $2 \mathrm{mSv} /$ час, два степена на магнитуда повеќе отколку максимално дозволената радијациона еквивалентна доза која е општоприфатена $(0.02 \mathrm{mSv} /$ час). Оваа еквивалентна доза е потврдена и од нашите процени засновани на специфичната $\alpha$-активност на ${ }^{238} U$ еднаква на специфичната $\beta$-активност од секој од неговите еквилибирачки потомци ${ }^{234} \mathrm{Th}$ и ${ }^{234 \mathrm{~m}} \mathrm{~Pa}$ и 
од степенот на еквивалентна доза предивикана од овие $\beta$ и $\gamma$-радионуклиди“ (NRC 1991). Помеѓу неотпакувани ОУ-ски куршуми, степенот на изложеност е до $0.02 \mathrm{mSv} /$ час. Но, бидејќи само рацете би можеле да бидат изложени до овој степен и затоа годишниот лимит на еквивалентната доза за телесните екстремитети е 10 пати повеќе отколку за целото тело.

„Акумулираната еквивалентна доза останува значајна кога употребени но неексплодирани ОУ-ски пенетратори се носат од воениот персонал како воен сувенир во директен контакт со кожата (18 Sv/год.) или кога се користени од децата како играчки“ (Siegwart.-Horst 1997). Годишниот лимит на еквивалентна доза за кожата од $0.5 \mathrm{~Sv} /$ година кај работниците кои се во контакт со зрачење може да биде достигнат за 10 дена. Според вообичаениот фактор од 50x, ние го постигнуваме годишниот лимит на еквивалентна доза за кожата од $0.01 \mathrm{~Sv} /$ година прокламиран за јавноста. Овој лимит би се постигнал приближно за 5 часа.

Степенот на еквивалентна доза за целото тело за екипажот на тенк оклопен со ОУ варира помеѓу $0,0004 \mathrm{mSv} /$ час за командирот до $0,0018 \mathrm{mSv} /$ час за возачот. Акумулираната еквивалентна доза за возачот би го постигнала годишниот општоприфатен лимит (1 mSv/ год. ) по 70 дена од 8-часовна смена.

\section{4. Истражувања со животни и луѓе кои работат со извори на зрачење}

Постојат широки докази за зголемена појава на рак на белите дробови кај подземните копачи на ураниум. Карциногеничниот причинител во рудниците е изотопот на радон ${ }^{222} \mathrm{Rn}$, член на сериите на ураиумскиот распад. Како благороден гас, тој не може да биде акумулиран во белите дробови и како таков е прилично безопасен. Но, продуктите од распадот на радонот се (солидни) цврсти и се формираат како хемиски реактивни јони кои брзо се врзуваат за честичките прав, предизвикан од човечката активност во рудниците, и се таложат во белите дробови кога ке бидат вдишани. Исто така, документирани се и невообичаени појави на рак кај поранешни произведувачи на часовници кои користеле радиумска боја, при што минијатурните четкички за боење ги остреле користејќи ги нивните јазици. (Изотопот на радиум ${ }^{226} \mathrm{Ra}$, исто така, е член на серијата на ураниумски распад).

Работниците кои го рафинирале ураниумот не покажале зголемена смртност или зголемена појава на рак на белите дробови и покрај нивното зголемено изложување на ураниумски прав и продуктите од распад на радон, при ураниумски концентрации $0,5-2,5 \mathrm{mg} / \mathrm{m}^{3}$ за 5 години. Не е дадено објаснување за оваа противречност, иако е веројатно дека рафинирачите се помалку изложени на самиот ураниумски прав отколку рударите.

Две проучувања ја поврзуваат малигноста на лимфните садови кај изложеноста на рафинирачите на ураниум, но според некои истражувачи (Harley et al. $1999,69)$ не бил предизвикувачкиот субјект ураниумот, туку ториумскиот изотоп ${ }^{230} \mathrm{Th}$ (присутен во ураниумската руда со малку помалку отколку половина од $\alpha$ активноста кај природниот ураниум и $88 \%$ од $\alpha$-активноста од осиромашениот 
ураниум). Друго проучување засновано на зголемена појава на смртност од леукемија не било во состојба да утврди дали постоела поврзаност со зрачење.

Работниците во објектите за процесирање метали, вклучувајќ ги оние кои произведуваат ОУ-ски пенетратори, не покажуваат зголемена смртност или рак на белите дробови. Но, ова не е изненадувачко. Работниците кои се изложени на радон или на вдишување на ураниумскиот прав, постојано се подложуват на тренинзи за радијација и, згора на тоа, регулирачките лимити за контакт со ураниум се засилени.

Поради високата хемиска токсичност, радиолошките ефекти од природниот или осиромашениот ураниум е тешко па дури и невозможно да се проучуваат кај лабораториските животни. Факт е дека хемиската токсичност е лимитирачки фактор за растворениот природен ураниум. Додека различни лабораториски животни толерираат $10 \mathrm{mg} / \mathrm{m}^{3}$ од (нерастворлив) $\mathrm{UO}_{2}$ за 5 години, зголемена смртност е забележена кај различни животни изложени до $19 \mathrm{mg} / \mathrm{m}^{3}$ од (растворлив $\mathrm{UO}_{2}$ за 33 часа/неделно за 4 недели. 50\% смртност била забележана кога глувците биле изложени до $8 \mathrm{~g} / \mathrm{m}^{3}$ на растворлив ураниум за 10 минути. Причината за смрт во повеќето случаи била хемиски индиуцирано откажување на бубрезите. Засновано на овие проучувања со животните, просечна летална доза за човекот (со 50\% очекувана смртност) може да биде постигната со $1 \mathrm{~g}$ од инхалиран растворлив ураниумски прав.

Различни типови рак, вклучувајќи и леукемија и рак на белите дробови и бубрезите, биле развиени кога животните биле изложени на збогатен ураниум $\left(93 \%\right.$ од $\left.{ }^{235} \mathrm{U}\right)$. Поради тоа што степенот на збогатен ураниум за оружје има за 2 реда од магнитуда повисока $\alpha$-активност споредено со ОУ (приближно $47 \mathrm{mCi} / \mathrm{kg}$, примарно поради попатно збогатување со ${ }^{234} U$ ), овие податоци се со мала релевантност за можната радијација - поврзана со здравствените ефекети од изложеноста на ОУ. Сепак, зголемувањето на радиоактивноста, додека токсичноста се одржува константна, може да ги одвои и направи видливи радиолошките ефекти, што може да се забележи во мали групи (здрави) лабораториски животни и тоа да биде екстраполирано до ниски еквивалентни дози во големи човечки популации, вклучувајќи и ранети индивидуи.

\section{Заклучок}

Прв пат откриен во XVIII век, ураниумот е природен елемент кој се наоѓa насекаде на Земјата, но, главно, во трагов квантитет, иако во Земјината кора постојат региони во кои се јавува зголемена концентрација на ураниумска руда. Ураниумската руда може да биде ископана со подземни или површински методи, зависно од длабочината на која се наоѓa. Со методот квасење во место рудата се промешува со киселина за да се растопи ураниумот кој потоа се издвојува од растворот. Крајниот продукт на фазите на копање и ронење, или ИСЛ, е концентрат на ураниум оксид (U3О8). 
Поради високата густина, ураниумот е употребуван во кобилицата на бродовите и како противтежа кај авионските контролни површини, како и за штит од радијација и производство на оклопно пробивна муниција.

Како и другите елементи, ураниумот се јавува во незначително различни форми познати како изотопи. Овие изотопи (16 во случајот на ураниум) се разликуваат едни од други по бројот на честичките (неутрони) во јадрата. Природниот ураниум кој се наоѓа во Земјината кора, главно, е мешавина од два изотопа: U-238 застапен со $99,284 \%$ и U -235 со околу $0,711 \%$. ${ }^{238} \mathrm{U}$ се распаѓа многу бавно, неговиот полуживот е истиот колку и староста на Земјата. Тоа значи дека е практично неуништлив.

ОУ кој се состои од $99,8 \%$ од ${ }^{238} \mathrm{U}$ се добива како спореден продукт при процесот на збогатување на ураниумот и класифициран е како радиоактивен и токсичен отпад. Во доволни количини, ОУ може да биде штетен поради неговата хемиска токсичност. Како живата, кадмиумот и другите јони на тешки метали, вишокот на ураниумски јони ја потиснуваат реналната функција. Висока концентрација во бубрезите може да ги оштети, а во екстремни случаи да предизвика и нивно откажување. Хемиската токсичност на ОУ го оневозможува проучувањето на неговите внатрешно телесни радиолошки ефекти. Поради тоа што ОУ поседува блага радиоактивност, откако ќе навлезе во телото ги озрачува органите. Познато е дека високите дози на зрачење предизвикуваат канцер. Општо е прифатено за радиолошки заштитни цели дека и ниските дози на зрачење предизвикуваат канцер, но колку е пониска дозата толку е помал ризикот. Доколку грутка ОУ се држи во раката, радијациската доза за кожата, која доаѓ, главно, од бета-честиците, лесно може да биде редуцирана со носење ракавици, или ако ОУ е затворен во некој друг материјал. За да предизвика радијациски изгореници или други брзи ефекти во ваков случај, ОУ би требало да дејствува со месеци. Теоретскиот максимум за целото тело озрачено со $\gamma$ надворешна доза, кој би можел да се достигне во практика, е во возилата кои имаат оклоп од ОУ и кои носат муниција од ОУ. Но, дури и тогаш, по околу 1.000 часа, екипажот би имал прием на доза слична на просечната годишна доза од вкупното природно зрачење кое го има во некои земји во светот. 


\section{Литература}

Board on Radiation Effects Research Division on Earth and Life Studies. 2003. A Review on the Dose Reconstruction Program of the Defense Threat Reduction Agency, Washington, D.C.: The National Academies press.

Clarke A., Hollett P., McCauley G., Hébert J., and Vlahovich S. 1998. Guide to Ionizing Radiation Exposures for the Occupational Physician, GMA-12, Canada: Canadian Nuclear Safety Commision (CNSC).

Department of Health and Human Services, Agency for Toxic Substances and Disease Registry (ATSDR). 2013. Toxicological Profile: Uranium and Compounds. Accessed July 19, 2013. http://www.atsdr.cdc.gov/ToxProfiles/tp150.pdf.

Gray, Henry. 1977. Anatomy, Descriptive and Surgical, New York: Bounty Books.

Harley Naomi, Foulkes Ernest, Hilborne H.Lee, Hudson Arlene, and Antony C.Ross. 1999. „Vol 7: Depeted Uranium “., A Review of the Scientific Literature As It Pertains to Gulf War Illnesses, MR-1018/7-OSD, Washington D.C.: RAND.

ICRP, 1980. Limits for Intakes of Radionuclides by Workers. ICRP Publication 30 (Part 2). Ann. ICRP 4 (3-4), New York: Pergamon Press

Leo, R. William. 1987. Techniques for Nuclear and Particle Physics Experiments, New York Berlin Heiderberg: Springer-Verlag.

Nicolson Garth, L. and Nicolson Nancy, L. 1998. „Gulf War Illnesses: Complex Medical and Scientific and Political Paradox." In Medicine, Conflict \& Survival vol 14, Huntington Beach: The Institute for Molecular Medicine.

Nuclear Regulatory Commission (NRC). 1991. Standards for Protection against Radiation, Title 10 of the Code of Federal Regulations (CFR), Part 20. Accesed March 18.2016. http://www.nrc.gov/reading-rm/doc-collections/cfr/part020/

Popović, Dragoslav. 1978. Nuklearna energetika, Beograd: Naučna Knjiga.

Saladin, Kenneth, S. 1999. Anatomy and Physiology: A unity of form and function, McGraw-Hill.

Siegwart.-Horst, Guenther. 1997. „How DU Shell Residues Poison Iraq, Kuwait and Saudi Arabia“. In Methal of Dishonor, New Yor City: International Action Center. 
Sergej CVETKOVSKI

\section{DEPLETED URANIUM: A RADIOLOGICAL OR TOXICOLOGICAL HAZARD}

\section{Summary}

First discovered in the 18th century, the uranium is a natural element that is found everywhere on Earth, but mainly in trace quantities, although in the Earth's crust there are regions where there is an increased concentration of uranium ore. The uranium ore may be dug underground or with surface methods, depending on the depth where is located. With ISL method the ore is mixed with an acid to dissolve uranium after which it separated from the solution. The final product of phase of digging and crushing or ISL, is a concentrate of uranium oxide $\left(\mathrm{U}_{3} \mathrm{O}_{8}\right)$.

Due to the high density the uranium is used in the keel of ships and as a counterweight in aircraft control surfaces, as well as a shield against radiation and production of armored piercing ammunition.

Like other elements, the uranium occurs in slightly different forms known as isotopes. These isotopes (16 in the case of uranium) differ from each other in the number of particles (neutrons) in the nuclei. Natural uranium that is found in the Earth's crust is mainly a mixture of two isotopes: $U-238$ represented with $99.284 \%$ and $U-235$ to about $0.711 \%$. The ${ }^{238} U$ decays very slowly, its half-life is the same as the age of the earth. This means that it is virtually indestructible.

$D U$ which consists of $99.8 \%$ of ${ }^{238} U$ is obtained as by-product in the process of enrichment of uranium, and is classified as toxic and radioactive waste. In sufficient quantities, DU could be harmful because of its chemical toxicity. As mercury, cadmium and other heavy metal ions, the excess uranium ions suppress renal function. High concentrations in the kidneys can damage them and in extreme cases can cause their failure. Chemical toxicity of DU prevents studying his internal body radiological effects. Because DU is mild radioactive, once entered the body it radiates the organs. It is known that high doses of radiation cause cancer. It is generally accepted for radiological protection purposes that low doses of radiation cause cancer too, but as the dose is lower so the risk is lower. If the DU lump is being hold in hand, radiation dose to the skin, which comes mainly from beta particles can easily be reduced by wearing gloves, or if $D U$ is enclosed in another material. To cause radiation burns or other promptly effects in this case the DU should act for months. The theoretical maximum for the whole body irradiated with $\gamma$ external dose, which could be achieved in practice, is in vehicles that are DU armored and equipped with DU ammunition. But even then, the crew at about 1000 hours would be dosed similar to the average annual total dose of natural radiation that occurs in some countries.

Keywords: DEPLETED URANIUM, ISOTOPES, EFFECT, RADIOACTIVITY, TOXICITY, LIMITS. 